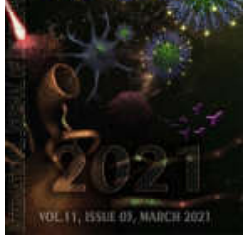

\title{
SUPPLY CHAIN AND INVENTORY MANAGEMENT: A BIBLIOGRAPHIC REVIEW
}

\author{
*Pedro Tenório de Holanda Rocha Libório
}

Graduated in Food Engineering at the Federal Rural University of Pernambuco, Garanhuns, Pernambuco, Brazil

\begin{abstract}
ARTICLE INFO
\section{Article History:}

Received $14^{\text {th }}$ January, 2021

Received in revised form

$26^{\text {th }}$ January, 2021

Accepted $16^{\text {th }}$ February, 2021

Published online $26^{\text {th }}$ March, 2021

\section{Key Words:}

Inventory management, Inventory Reduction, Control Systems, Process Improvements.

*Corresponding author:

Pedro Tenório de Holanda Rocha Libório,

ABSTRACT

In order for stocks to be used with the lowest level of losses possible, there is a need to use control systems. This scientific article has a review about the stock in general, where it is discoursed on definition, classification and inherent costs as also inventory management, highlighting models and methods for their management. Some of the main indicators used in inventory management are presented, such as physical inventory, inventory accuracy, service level, inventory coverage, demand versus consumption, stock location, inventory reduction and $\mathrm{ABC}$ curve. Inventory management helps companies achieve adequate levels of inventory, thus ensuring greater product availability to the consumer with as little inventory as possible. Such control allows the manager to identify flaws and opportunities for improvement in the process. The inventory management theories in the article could be used by inventory managers who seek to improve and optimize their process. This research conducts a review of the main inventory management methods, and the main resources and benefits in stock control. The inventory management techniques described in the article can be implemented by managers without the need for advanced knowledge of statistics and programming. These are fundamental technical practices, which serve as a basis for the possible implementation of inventory management procedures.
\end{abstract}

Copyright (C) 2021, Pedro Tenório de Holanda Rocha Libório. This is an open access article distributed under the Creative Commons Attribution License, which permits unrestricted use, distribution, and reproduction in any medium, provided the original work is properly cited.

Citation: Pedro Tenório de Holanda Rocha Libório, 2021. "Supply chain and inventory management: A Bibliographic Review", International Journal of Development Research, 11, (03), 45368-45371.

\section{INTRODUCTION}

To remain in the market, organizations must always be attentivemarket trends, improve performance and add value to productsand services. Inventory management helps ensuring greater availability of product to the consumer withas little inventory as possible. Reducing inventory improves profitabilityof the company, since the capital in movement will be greater (MARTELLI, 2015). When dealing with inventory management, it is necessary to have a larger viewcontrol of material resources. Care with storage is alsonecessary in organizations, because knowing where to place, what to place, how muchproduct to stock and what means of transport to use, maintaining efficient managementin these processes, it is of fundamental importance for adding value to thebusiness (MARTELLI, 2015). Inventory management reflects the results obtained by the company in thefinancial year. If the person in charge of stock management does not beable to predict and plan their decisions regarding the movements made in theinventory, there may be a disorderly increase in inventory or an insufficientinventory (SILVEIRA, 2017). To avoid the excess or lack of products in stock, it must be managedfocused on reducing the invested capital, keeping it within the levels ofsecurity to achieve the demand.
Low stock can cause high costs due to lack of products, however, high inventory can lead to costsunnecessary operating costs and affect the company's working capital. So, for agood inventory control, items must be purchased according to demand, reducing its cost without compromising the service level (SILVEIRA, 2017). The main purpose of inventory control is to compensate for errors indemand forecast and resupply time. Such control allows the manager tomaking purchases according to the demand of its customers and identificationfailures and opportunities for process improvements. Product storageit requires large investments, which can cause disruptions in the company's cash. Managing inventories correctly can generate competitive advantage andgrowth in the market (KOGIK, 2018). The optimization of stock management enables gains with efficiency, reductionerrors and costs. Thus, the objective of this research is to conduct a review of themain inventory management methods, pointing out their main characteristicsand inventory control benefits.

\section{MATERIAL AND METHODS}

This study is classified as descriptive, aiming to analyse thescientific production published in the period between 2015 and 2020. It was 
developed through references related to the thematic "Inventory Management". The search for the articles was carried out on 2020 using the keywords "inventory management", "inventory control", "stock methodologies" and "stock management". Descriptive research records, analyses and correlates facts or phenomena without manipulating them. Seeks to discover, as accurately aspossible, the frequency with which a phenomenon occurs, its relationship andconnection with others, their nature and characteristics. The nature of the article is classified as a bibliographic search, beingcarried out through the survey of published scientific articles. AccordingMacedo (1994), bibliographic research consists of searching for informationbibliography, selection of documents that relate to the problem ofresearch and the respective file of references so that they can be later used (ANDRADE, 2015).

\section{RESULTS AND DISCUSSION}

Stock and Logistics: Inventories are considered to be fixed capital because they do not generate profits for organization, but it also avoids the lack of products, ensuring the demand of the customer. Inventory management seeks to balance supply and demand, the more accurate the demand forecast, the simpler is inventory control. As these predictions are hardly accurate, the companies use inventories to reduce effects caused by the difference between supply and demand (PEREIRA, 2015). Different types of stock can be stored in different ways, centralized in a warehouse, or distributed in several points within the company. Inventories are part of the biggest concerns of operations. In the operational view, low inventory means unavailability of customer service, already in the financial view, high inventory means money stopped (PEREIRA, 2015). Logistics manages the strategic process of acquisition, handling and storage of materials, pieces, finished products and related information. The main objective is to maximize profitability by filling orders at low cost. It covers from the acquisition process of the products to be used until the end customer service, conducting its activities for its satisfaction and reduction of costs incurred by the production system (ANDRADE, 2015).

Stock Types: The classification of the types of stock is necessary so that it can beknow which situation the item is in. The materials used in a unitare resources that can be classified into direct and indirect materials. Direct materialsare those that are added to the final product, while indirect materials are notadded to the final product, such as lubricating oils used in a machineduring its production process (SANTOS, 2009). According to research done by Silva in 2015 , stocks are classified into five broad categories. Stock of materials: items used in the processes oftransformation into finished products. Are part of thisstock all stored materials that the company buys to use in the production process, auxiliary materials that areitems used by the company, but that have little or nothing related to the production process, such asoffice materials.Inventories of products in process: items that have already enteredin the production process, but they are not yet finished products. These are materials that started to undergo changes, but stillare not finished.Finished product inventories: items that are readyto be delivered to final consumers. In-transit stocks: products that were shipped from amanufacturing unit to another, normally subsidiary, but not yetreached their final destination. Consignment stock: materials that continue to beproperty of the supplier until they are sold. If notsold, are returned free of charge.

Inventory Cost: The need to maintain inventories entails a series of costs for companies. The costs of maintaining inventories can be classified into threebroad categories: costs directly proportional to inventories; inverselyproportional to inventories andindependent of the quantity stored (SANTOS, 2009). The costs directly proportional to the stock increaseswiththe average amount stored. The bigger the stock, the higher the cost of capitalinvested, as well as the greater the quantity of items stored, the greater thenecessary areas and higher real estate cost. This category includes the cost ofcapital, which corresponds to the cost of capital invested, and the cost of storage, which refers to the sum of other cost factors, such as storage, handling and losses. It is difficult to accurately predict future demand, making it necessary to maintainstock level to ensure product availability. However, stocks absorb capital that could be invested in otherinvestments. Turnover releases the asset and reduces the cost of maintaining thestock. Therefore, an adequate inventory management is necessary so thathave too much or too little material (PEREIRA, 2015). The ideal number of warehouses for a given distribution systemmust also be checked. Inventory costs increase proportionallywith the number of warehouses due to the stock level that must be higher for serve more distribution units. The cost of processing the order and thetechnology spending also increases with the increase in the number of warehouses. Theprocessing cost involves the transmission and processing of orders, entries and movements, while the need for investments ininformation technology is necessary for system integration. The cost oftransport, however, is inversely proportional to the number of warehouses. The biggestnumber of warehouses leads to a reduction in the distance between the product and the customer.

Inventory Management: Stocks have the function of regulating business flows. It is necessarythat companies have a well-defined inventory policy, where it should bepresent the principles by which the supply and departure products, follow. Organizations must set the time to deliver aproduct to the customer; the number of deposits and their respective locations; thematerials that will be stored in each warehouse; the level of flexibility to the customer, anticipate purchases aiming at lower acquisition costs, delivery priority, among others. Such policies guide the unit's logistical flow making it morecompetitive in the market (ANDRADE, 2015). Managing stocks corresponds to making decisions that involvepurchasing, production, quality, sales and finance departments. It's neededintegrate and control quantities and values of all quantities involved. Increasing the efficiency of the use of internal resources leads to cost savings, less waste and greater efficiency of the process as a whole (ANDRADE, 2015). There are several productivity indicators in the analysis and control ofstocks. Physical inventory, inventory accuracy, service level, service coverageinventory, demand versus consumption, inventory location, inventory reduction, $\mathrm{ABC}$ curve, among others.

Physical Inventory: Inventory is a way to keep the stock up to date. Such a process shouldbe done regularly. Its accuracy must be considered of extreme importanceto maintain high levels of productivity and profitability. Monitoring ofinventory is the best way to avoid erroneous counting, providing bettereffectiveness in the result. The inventory results allow changes to correct any process errors (KOGIK, 2018). The inventory makes it possible to find and analyse errors in the stock, comparing the numbers collected in the inventory and the data provided by your system.

Inventory Accuracy: The accuracy index refers to the level of reliability of the stock, measures the percentage of correct items in inventory, uses data taken from inventoryand can be calculated by dividing the number of correct items by the number of items scanned, the result is multiplied by 100 .

Service level: It is an indicator of how effective the stock was to support customer requests users. The more requests are supported, in quantities and specification, the higher the service level of the organization. It can be calculated by dividing the number of requests supported by the number of requests that were made, the result is multiplied by 100 .

Stock coverage: Indicates the number of times units that the average stock will be enough to cover average demand. Inventory management can be used based on current levels anddesired. Inventory management through turns is based on factors such ascost of sales and average quantity of inventory divided by the annual cost of aperiod (SILVA, 2016).

Demand versus consumption: Demand forecasts are essential for planning and controllingall areas of the organizations, being essential 
mainly for the areas of logistics, marketing, production and finance. Accurate forecasts allow development of consistent strategies, better allocation of resources andidentification of priorities (ANDRADE, 2015). Forecasting methods can be divided into quantitative and qualitative. The qualitative ones depend on the experience accumulated by the specialists, being able toaccompanied by formal analysis or not. The qualitative forecast is indicatedwhen data are insufficient or inadequate for quantitative analysis. Alreadyquantitative methods are based on quantitative data and can besubdivided into time series methods, which involves statistical analysis of past data; and causal methods, which are based on statistical analyses ofpast achievements (ANDRADE, 2015). The initial activity for demand management consists basically of thepredictive market analysis to understand the future needs of consumers. Knowledge of demand allows companies to maintainthe correct amount of available stock. An inconsistent forecast can resultlack of material and, consequently, lead to declines in sales or an excessive amount of stock (MARCHESAN NETO, 2015). horizontal "B" positions the pallets arestored one floor above the floor, and in horizontal " $\mathrm{C}$ " positions, the palletstwo floors above the floor are stored.

The address for the location of the pallets in the warehouse follows the rule AA.BB.CC. Where AA is the street number, $\mathrm{BB}$ is the vertical position and $\mathrm{CC}$ is the horizontal position inside the vertical position. The warehouse hasthe capacity to allocate 774 pallets.

Inventory reduction: Managers are constantly trying to reduce stocks, be they raw materials, semi-finished products, or finished products. This search has led todevelopment of new management techniques and management philosophies. The search for a better use of stocks led to the developmentof methods like just-in-time. The term means that each process must be suppliedwith the right items and quantities, at the right time and place. Initially, just-in-time was defined as the ability to obtainappropriate amount of material at the right time, but the method is notconcentrates only on the material

\begin{tabular}{|c|c|c|c|c|c|c|c|c|c|c|c|}
\hline 0161 & \multirow{31}{*}{ 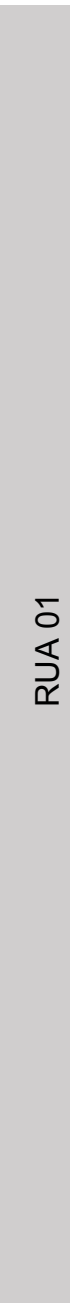 } & 0162 & 0261 & \multirow{31}{*}{ 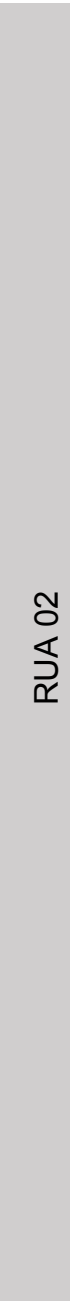 } & 0262 & 0361 & \multirow{31}{*}{ 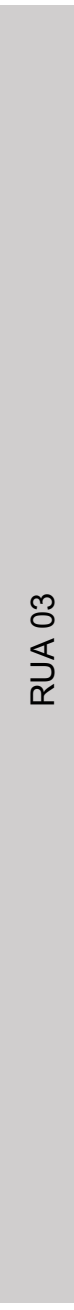 } & 0362 & 0461 & \multirow{31}{*}{ 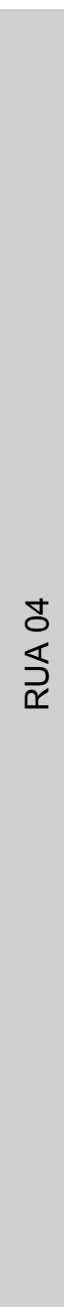 } & 0462 \\
\hline 0159 & & 0160 & 0259 & & 0260 & 0359 & & 0360 & 0459 & & 0460 \\
\hline 0157 & & 0158 & 0257 & & 0258 & 0357 & & 0358 & 0457 & & 0458 \\
\hline 0155 & & 0156 & 0255 & & 0256 & 0355 & & 0356 & 0455 & & 0456 \\
\hline 0153 & & 0154 & 0253 & & 0254 & 0353 & & 0354 & 0453 & & 0454 \\
\hline 0151 & & 0152 & 0251 & & 0252 & 0351 & & 0352 & 0451 & & 0452 \\
\hline 0149 & & 0150 & 0249 & & 0250 & 0349 & & 0350 & 0449 & & 0450 \\
\hline 0147 & & 0148 & 0247 & & 0248 & 0347 & & 0348 & 0447 & & 0448 \\
\hline 0145 & & 0146 & 0245 & & 0246 & 0345 & & 0346 & 0445 & & 0446 \\
\hline 0143 & & 0144 & 0243 & & 0244 & 0343 & & 0344 & 0443 & & 0444 \\
\hline 0141 & & 0142 & 0241 & & 0242 & 0341 & & 0342 & 0441 & & 0442 \\
\hline 0139 & & 0140 & 0239 & & 0240 & 0339 & & 0340 & 0439 & & 0440 \\
\hline 0137 & & 0138 & 0237 & & 0238 & 0337 & & 0338 & 0437 & & 0438 \\
\hline 0135 & & 0136 & 0235 & & 0236 & 0335 & & 0336 & 0435 & & 0436 \\
\hline 0133 & & 0134 & 0233 & & 0234 & 0333 & & 0334 & 0433 & & 0434 \\
\hline 0131 & & 0132 & 0231 & & 0232 & 0331 & & 0332 & 0431 & & 0432 \\
\hline 0129 & & 0130 & 0229 & & 0230 & 0329 & & 0330 & 0429 & & 0430 \\
\hline 0127 & & 0128 & 0227 & & 0228 & 0327 & & 0328 & 0427 & & 0428 \\
\hline 0125 & & 0126 & 0225 & & 0226 & 0325 & & 0326 & 0425 & & 0426 \\
\hline 0123 & & 0124 & 0223 & & 0224 & 0323 & & 0324 & 0423 & & 0424 \\
\hline 0121 & & 0122 & 0221 & & 0222 & 0321 & & 0322 & 0421 & & 0422 \\
\hline 0119 & & 0120 & 0219 & & 0220 & 0319 & & 0320 & 0419 & & 0420 \\
\hline 0117 & & 0118 & 0217 & & 0218 & 0317 & & 0318 & 0417 & & 0418 \\
\hline 0115 & & 0116 & 0215 & & 0216 & 0315 & & 0316 & 0415 & & 0416 \\
\hline 0113 & & 0114 & 0213 & & 0214 & 0313 & & 0314 & 0413 & & 0414 \\
\hline 0111 & & 0112 & 0211 & & 0212 & 0311 & & 0312 & 0411 & & 0412 \\
\hline 0109 & & 0110 & 0209 & & 0210 & 0309 & & 0310 & 0409 & & 0410 \\
\hline 0107 & & 0108 & 0207 & & 0208 & 0307 & & 0308 & 0407 & & 0408 \\
\hline 0105 & & 0106 & 0205 & & 0206 & 0305 & & 0306 & 0405 & & 0406 \\
\hline 0103 & & 0104 & 0203 & & 0204 & 0303 & & 0304 & 0403 & & 0404 \\
\hline 0101 & & 0102 & 0201 & & 0202 & 0301 & & 0302 & 0401 & & 0402 \\
\hline$(A, B, C)$ & & $(\mathrm{A}, \mathrm{B}, \mathrm{C})$ & $(A, B, C)$ & & $(A, B, C)$ & $(A, B, C)$ & & $(A, B, C)$ & $(A, B, C)$ & & $(\mathrm{A}, \mathrm{B}, \mathrm{C})$ \\
\hline
\end{tabular}

Figure 1. Outline of hypothetical warehouse

Inventory Location: Inventory location is how items will be addressed andstored so that they can be easily located. With the automation of deposits, it is possible to define a criterion foraddressing so that products can be easily located with theaid of information tools. There are several ways a deposit can beorganized, being the manager's responsibility to identify and standardize the bestform for its operation. Figure 1 shows an example of how a deposit can be configured. It is made up ofpallet racks that allows the allocation of one pallet per position. The deposit wasdivided into four streets, streets 1, 2, 3 and 4. Each street contains 62 vertical positions, being that on the left side there are odd positions and on the right sidethe even positions. Each vertical position is subdivided into three horizontal positions, represented by the letters "A", "B" and "C". In horizontal "A" positions, the pallets arestored directly on the floor, in flow. Over the years, the method has evolved and came to be seen as a series of actions, such as improving the control ofinventory, and a better production plan, focused on fundamental activities andcontinuous quality improvement. The just-in-time aims to improveefficiency of the production line, aiming to obtain products and services at the lowest cost andas quickly as possible. To this end, efforts should be made to reduce waste and to use a system that provides production control (MOURA, 2017). Toyota, creator of the just-in-time approach, identified seven types ofwaste that affects both service and manufacturing operations. Amongthe points identified by Toyota, there is the waste for transportation, which is the timetotal waiting time for materials that are waiting to be processed, while operators are producing in-process inventory; waste 
by movement, where sometimes, no value is being added to anoperator who may apparently be busy. Therefore, the simplification ofwork is a great source of waste reduction; and the stock, which shouldbecome a target of elimination. To reduce it, it is necessary to eliminate its origins (MOURA, 2017)

ABC curve: The ABC curve has its specific use for studies offinished product inventories, sales, production scheduling priority, taking prices on supplies and sizing inventory. Its function isallowing for quick decision-making and action that can bring your outcome to agreat positive impact on the company's. The ABC curve can be divided into dataobtained in three categories, class $\mathrm{A}, \mathrm{B}$ and $\mathrm{C}$ (SILVA, 2017). In class A are the most important items from which they must receive all theattention at the first moment of the study. Decisions must be made about theitems in that class. The data classified in this class correspond, on average, to $80 \%$ of the total monetary value and importance and a maximum of $20 \%$ of the items studied. In class B are the intermediate items that should be treated after theitems of class A. The data classified in this class correspond, on average, to $15 \%$ of the total stock value and monetary value and a maximum of $30 \%$ of the itemsstudied. Class $\mathrm{C}$ includes items of lesser importance. There arelarge volume of items, but with reduced monetary value, which allows agreater time for its analysis and action. Should be treatedafter classes A and B. In general, $5 \%$ of the total amount and monetary valuethey represent this class, however more than $50 \%$ of the items to form. Knowledge of tools that will assist in improving the stock management in companies is essential. With technologies eachmore and more advanced, the importance and need for improvement in companies. For companies to be effective in their control ofit is necessary to maximize profit and decrease waste. Therefore, the company that best manages its inventory will be in a position to competewith competitors with a great competitive advantage. Kogik (2018) pointsthat the lack of accuracy in the inventory makes stocks uncertain and reducesprofits, and in order for companies to be effective in controlling inventory, it ismaximizing profits and reduce waste. Well-trained and motivated employees can make a difference ininventory management. The role of the manager, in addition to being concerned withprocess, taking care of the people who are carrying out the processes. Spacewellstructured physical environments, with well-demarcated storage areas, make greater use of available software, thus being able to better meet your needs, as well as the use of performance indicators such as the $\mathrm{ABC}$ curve, can beindispensable, as they allow better control, in addition to providing greater capacity foractions. Martelli (2015) indicates that the company must define a setcomprehensive range of performance indicators, where effective management ofchange and user training are essential to adapt people innew tools. There are several stock control methods that if used by managers guarantee improvement in the management and quality of the processes of thedeposit. All the methods presented in this article can be easilyimplemented by improving deposit control. Such methods have also beendiscussed by actors such as Kogik (2018), Silva (2017) and Martelli (2015). Well-defined processes and strict control on input and output, are essential for the manager, since poorly implemented processes or poorlyplanned activities can lead to other possible inconveniences. Good communicationbetween departments can avoid misinformation, thus facilitating progress procedures adopted by the company, supervision of all items mentionedas well as the correct analysis of data will bring better results for the manager. Devesa (2016) talks about the importance of communication in the organizational context, where it emphasizes that good organizational communication leads to the formation of a spiritof help, which facilitates the work in the company.

\section{Conclusion}

This article focused on definitions and methods for inventory management.
To avoid excess or lack of products in stocks, it must be administered withfocus on reducing the invested capital, keeping it within security levelsto support the demand.Inventory management is fundamental to assist the decision making of themanager, and represent the main challenge for material management, beingessential for business growth and production optimization. The main purpose of inventory control is to compensate for errors indemand forecast and resupply time. Its optimization allowsgains with efficiency, reduction of errors and costs. Therefore, management ofadequate stock so that there is no excess or missing material.The appropriate means of control to mastery stock levels should bedeveloped based on the demand pattern of each product. Management techniquesinventories described in the article can be implemented by managers without theneed for advanced knowledge of statistics and programming. Fundamental techniques were presented, which will serve as a basis for the possibleimplementation of more complicated management procedures.

\section{REFERENCES}

ANDRADE, R. Q. E. Gestão de estoques: uma revisão teórica dos conceitos e características. XXXI Encontro Nacional de Engenharia de Produção, Belo Horizonte, 2015.

DEVESA, L. M. A importância da comunicação no contexto organizacional. 2016. Dissertação (Mestre em Ciências Empresariais). Instituto Politécnico de Setúbal, Setúbal.

KOGIK, A. V.; SILVA, A. M.; BELUSSO, M. WERLANG, R. A importância do gerenciamento estratégico do estoque no setor supermercadista. UCEFF, Chapecó, v. 2, n. 1, 2018.

MACEDO, N. D. Iniciação à pesquisa bibliográfica - guia do estudante para a fundamentação do trabalho de pesquisa. Loyola, São Paulo, 1994.

MARCHESAN NETO, C.; CASALENOVO, M. B.; ALBORGHETTI, M.; GIUSEPPIN, V. S. Otimização de estoque: estudo de caso do almoxarifado de embalagens de um frigorífico. Trabalho de Conclusão de Curso em Administração de Empresas, Faculdade G\&P, Pederneiras, 2015.

MARTELLI, L. L.; DANDARO, F. Planejamento e controle de estoque nas organizações. Revista Gestão Industrial, Paraná, v. 11, n. 2, p. 170-185, 2015.

MOURA, R. E. L.; RUZENE, D. S.; SILVA, D. P. O just in time como método de planejamento e controle: uma revisão bibliográfica. IX Simpósio de Engenharia de Produção de Sergipe, 2017.

PEREIRA, B. M.; CHAVES, G.; BELLUMAT, M. S.; BARBOZA, M. V.; DUTRA, R. V. Gestão de estoque: um estudo de caso em uma empresa de pequeno porte de Jaguaré. XXXV Encontro Nacional de Engenharia de Produção, Fortaleza, 2015.

SANTOS, L. C. G. V. A gestão de estoque com apoio à otimização da produção. 2009. Dissertação (Especialização em Engenharia de Produção) - Universidade Candido Mendes, Rio de Janeiro.

SILVA, G. K. C. B.; MATEUS, E. S.; SILVA, A. L. G. Análise de sistema de estoques por meio de análise de curva $\mathrm{ABC}$ e giro de estoque: um estudo de caso numa organização hospitalar pública. XXXVI Encontro Nacional de Engenharia de Produção, 2016.

SILVA, M. G.; RABELA, M. H. S. Importância do controle de estoques para as empresas. Revista Acadêmica, v. 2, n. 1, p. 238254, 2017.

SILVEIRA, V. C.; NÓBREGA, D. C.; EDUARDO, A. S.; CHAEVO, G.; RIBEIRO, J. S. Estudo da gestão de estoques a partir das publicações científicas nos últimos 10 anos. I Encontro Internacional de Gestão, Desenvolvimento e Inovação, Naviraí, 2017. 